\begin{tabular}{|c|c|}
\hline 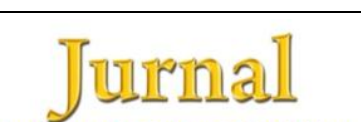 & $\begin{array}{l}\text { Jurnal Penelitian dan Evaluasi Pendidikan } \\
\text { Volume 21, No 2, December } 2017 \text { (162-174) }\end{array}$ \\
\hline an dan Evaluasi Pendiditkan & Online: http://journal.uny.ac.id/index.php/jpep \\
\hline
\end{tabular}

\title{
FAKTOR-FAKTOR YANG MEMPENGARUHI KEARIFAN KONSELOR MENURUT PERSPEKTIF CALON KONSELOR ETNIS JAWA
}

\author{
H. Herdi ${ }^{1}$, Sunaryo Kartadinata ${ }^{1}$, Agus Taufiq ${ }^{1}$ \\ ${ }^{1}$ Universitas Pendidikan Indonesia \\ * Corresponding Author. Email: herdiunj5@student.upi.edu
}

${ }^{1} J a l a n$ Setiabudhi No. 229, Isola, Sukasari, Kota Bandung, Jawa Barat 40154, Indonesia

\begin{abstract}
Abstrak
Tujuan penelitian ini adalah mengeksplorasi faktor-faktor yang mempengaruhi kearifan konselor menurut perspektif calon konselor etnis Jawa. Penelitian menggunakan metode deskriptif jenis survey. Sampel penelitian berjumlah 270 calon konselor etnis Jawa semester enam dari 11 Program Studi Bimbingan dan Konseling di Indonesia. Sampel penelitian dipilih menggunakan teknik purposive sampling. Pengumpulan data menggunakan angket yaitu Skala Anteseden Kearifan Konselor yang berbentuk skala lima jenjang. Teknik analisis data menggunakan statistik deskriptif dan analisis faktor eksploratoris. Hasil penelitian menunjukkan terdapat enam faktor yang mempengaruhi kearifan konselor menurut perspektif calon konselor etnis Jawa. Faktor-faktor yang dimaksud dinamakan: (1) kepribadian dan kecerdasan, (2) pengalaman, (3) atribut pribadi, agama, dan spiritual; (4) keterampilan metakognitif (berpikir kritis dan mendalam); (5) konteks fasilitatif; dan (6) kepakaran (profesionalitas).
\end{abstract}

Kata kunci: calon konselor, etnis Jawa, faktor-faktor yang mempengarubi kearifan, kearifan, pendidikan konselor

\section{THE FACTORS AFFECTING A COUNSELOR'S WISDOM IN THE PERSPECTIVES OF JAVANESE PRE-SERVICE COUNSELORS}

\begin{abstract}
The purpose of this research is to explore the factors affecting a counselor's wisdom in the perspectives of Javanese pre-service counselors. The research adopted a descriptive method of survey. The sample included 270 of the sixth semester of Javanese pre-service counselors from 11 Guidance and Counseling Study Program in Indonesia. Data were collected using questionnaire, which is Counselor Wisdom Antecedents Scale, in the form of five-level scale. The data were analyzed with descriptive statistics and exploratory factor analysis. The findings show that there are six factors affecting a counselor's wisdom in the perspectives of Javanese pre-service counselors. The six factors named: (1) personality and intelligence, (2) experience, (3) personal attributes, religiosity, and spirituality, (4) metacognitive skills (critical and in-depth thinking skills), (5) context-facilitative, and (6) expertise (professionality).

Keywords: counselor education, factors affecting counselor's wisdom, pre-service counselor, Javanese ethnic, wisdom
\end{abstract}

Permalink/DOI: http:/ / dx.doi.org/10.21831/pep.v21i2.13199 


\section{Pendahuluan}

Kearifan menjadi isu penting yang mendapat perhatian serius para pakar dalam berbagai bidang ilmu, khususnya pendidikan, psikologi, dan konseling. Dalam pendidikan, kearifan dipertimbangkan dan ditetapkan kembali sebagai tujuan pendidikan (Marshall \& Thornburn, 2014 p. 1541), baik di jenjang sekolah menengah (Sternberg, 2001, p. 227; 2013, p. 44) maupun pendidikan tinggi kontemporer (Barris \& Ruff, 2012, p. 5; Jones, 2015, p. 1), termasuk pendidikan bagi orang dewasa (Ardelt, 2000a, p. 772) dan pendidikan konselor (Osterlund, 2016, p. 12) setelah sekian lama terabaikan.

Dalam konseling multibudaya, kearifan tampil sebagai komponen konseling yang penting, kualitas fundamental kepribadian, dan kompetensi konselor multibudaya yang efektif (Hanna \& Ottens, 1995, p. 195; Hanna, Bemak, \& Chung, 1999, p. 125; Osterlund, 2014, p. 74), namun cenderung terabaikan dalam literatur dan praktik konseling multibudaya (Phan, Rivera, Volker, \& Maddux, 2009, p. 157). Konselor yang efektif tidaklah cukup dengan kecerdasan intelektual saja, tetapi memerlukan kearifan (Levitt \& Fiazza-Bonin, 2016, p. 40). Hanna, Bemak, \& Chung (1999, p. 131) mengemukakan pentingnya kearifan sebagai berikutp. "Kearifan meliputi dan menembus kondisi inti konselor yang efektif karena menekankan pada kecakapan metakognisi, kesadaran, empati, keaslian, penerimaan tanpa syarat, kekonkretan, keterbukaan, kedalaman, kelenturan, dan kekayaan pemahaman terhadap konseli dan/atau sistem konseli yang beragam latar belakang budayanya."

Karakteristik kearifan lebih penting daripada kecerdasan intelektual bagi konselor multibudaya yang efektif (Hanna, Bemak, \& Chung, 1999, p. 127). Sebaliknya, konselor multibudaya yang hanya memiliki kecerdasan intelektual tanpa kearifan tidak dapat melindungi dari dan hanya akan terjebak ke dalam perilaku "foolishness" (Sternberg, 2005 a, p. 241; 2005b, p. 332) yang dapat membahayakan dan menggagalkan hubungan, proses, maupun hasil konseling.
Belum ada konsensus di antara para pakar tentang konsep dan anteseden kearifan walaupun beberapa upaya telah dilakukan (Jeste, Ardelt, Blazer, Kraemer, Vaillant, \& Meeks, 2010, p. 668). Kesulitan mendapatkan konsensus tentang konsep dan anteseden kearifan karena keduanya merupakan "produk kolektif dan budaya" (Baltes \& Staudinger, 2000, p. 127). Setiap budaya memandang konsep dan anteseden kearifan secara berbeda-beda (Takahashi \& Overton, 2002 , p. $275 ; 2005$, p. 32). Ardelt (2000b, p. 361; 2003, p. 277; 2004, p. 275; 2010, p. 198; 2011, p. 245) mendefinisikan kearifan sebagai "integrasi karakteristik kepribadian, meliputi kognitif, reflektif, dan afektif." Pakar the Balance Theory of Wisdom mendefinisikan kearifan sebagai "penerapan pengetahuan tasit yang dimediasi oleh nilai-nilai untuk menyeimbangkan kepentingan intra, antar, dan ekstrapribadi demi mencapai kemaslahatan umum." (Karelitz, Jarvin, Sternberg, 2010, p. 855; Sternberg, 1998, p. 353; Sternberg, 2001, p. 231; Sternberg, 2005a, p. 241; Sternberg, Jarvin, \& Reznitskaya, 2008, p. 38-39). Pakar the Berlin Wisdom Paradigm mendefinisikan kearifan sebagai "pengetahuan pakar dalam pragmatika kehidupan yang mendasar." (di antaranya Baltes \& Smith, 1990, p. 87; Baltes, Gluck, \& Kunzmann, 2005, p. 331). Kearifan juga merupakan integrasi yang sempurna antara pikiran dan karakter (Staudinger \& Gluck, 2011, p. 231). Kearifan juga didefinisikan sebagai kecakapan menemukan dan mengatasi masalah (Arlin, 1990, p. 231), master kebajikan yang penting untuk membuat keputusan dan mengatasi masalah (Schwartz \& Sharpe, 2005, p. 1), dan bentuk kebajikan filosofis konselor dalam membimbing konseli mengatasi masalah, mengambil keputusan, dan mencapai kehidupan yang lebih baik (Tukiainen, 2010, p. 48-49).

Mengingat pentingnya kearifan, maka perlu dikembangkan dalam diri (calon) konselor pada pendidikan konselor. Kearifan tidak berada dalam kevakuman, namun bergerak dan berkembang secara dinamis. Hasil kajian meta-analisis Kunzmann \& Baltes (2005, p. 120) menunjukkan terdapat tiga 
faktor yang mempengaruhi kearifan, yaitu: Pertama, faktor konteks, meliputi: usia, interaksi sosial, konteks pendidikan, budaya, dan agama. Kedua, faktor kepakaran, seperti: mentor/model peran, praktik berkelanjutan, pengalaman hidup, dan pendidikan/ pelatihan profesional. Terakhir, kecerdasan, ciri-ciri kepribadian, kompetensi emosional, dan motivasi.

Hasil penelitian Gluck \& Bluck (2011 p. 3) terhadap 1955 partisipan masyarakat awam yang menekankan pandangan kognitif dan integratif menemukan sembilan faktor yang mempengaruhi perkembangan kearifan, yaitu: (1) pengalaman positif dan negatif, (2) belajar dari orang yang arif, (3) pengalaman menghadapi peristiwa negatif, (4) belajar filsafat, (5) mengkonfrontasi kematian, (6) mengkonfrontasi ketidakpastian, (7) bertambah usia, (8) pengalaman religius/ spiritual, dan (9) mengikuti bimbingan spiritual secara bertahap. Partisipan masyarakat awam yang menekankan pandangan kognitif menilai faktor yang penting, yaitu (1) belajar dari pengalaman positif dan negatif, dan (2) belajar dari orang yang arif. Sementara itu, partisipan masyarakat awam yang menekankan pandangan integratif menambahkan peran emosional dalam menyikapi pengalaman positif dan negatif selain kedua faktor dominan tersebut.

Kajian teoretik maupun empirik tentang faktor-faktor yang mempengaruhi kearifan secara umum telah banyak dilakukan oleh para pakar dan peneliti di dunia internasional. Namun, penelitian tentang faktorfaktor yang mempengaruhi kearifan konselor belum pernah dilakukan, baik di Indonesia maupun dunia internasional. Padahal, kajian ini dapat berkontribusi terhadap upaya-upaya pengembangan kearifan konselor dalam program pendidikan konselor di Indonesia. Orwoll \& Perlmutter (1990, p. 176) menyarankan pentingnya mengkaji berbagai faktor yang mempengaruhi kearifan, meliputi: usia, jenis kelamin, pendidikan, status sosio-ekonomi, latar belakang budaya, dan etnis.

Atas dasar rasional tersebut, penelitian ini difokuskan pada pengkajian tentang faktor-faktor yang mempengaruhi kearifan konselor menurut perspektif calon konselor etnis Jawa. Rumusan masalah yang diajukan yaitu faktor-faktor yang mempengaruhi kearifan konselor menurut perspektif calon konselor etnis Jawa.

\section{Metode Penelitian}

Metode penelitian yang digunakan yaitu deskriptif jenis survey karena dimaksudkan untuk mengidentifikasi atau mengeksplorasi berbagai fakta, pendapat, sikap, dan perilaku tertentu (Heppner, Wampold, \& Kivlighan, 2008, p. 226). Hal yang yang diidentifikasi atau dieksplorasi yaitu faktorfaktor yang mempengaruhi kearifan konselor menurut perspektif calon konselor etnis Jawa.

Penelitian dilaksanakan pada bulan Februari-Juni 2016. Populasi penelitian terjangkau yaitu 562 mahasiswa (calon konselor) etnis Jawa semester enam dari 11 Program Studi Bimbingan dan Konseling (BK) di Indonesia. Sampel penelitian dipilih menggunakan teknik purposive sampling. Kriteria yang ditetapkan yaitu: (1) terdaftar secara administratif sebagai mahasiswa semester enam; (2) telah atau sedang mengikuti perkuliahan teori dan praktikum konseling dan pengembangan pribadi konselor; dan (3) berlatar belakang etnis Jawa. Jumlah anggota sampel yang dibutuhkan berjumlah berjumlah 280 calon konselor etnis Jawa yang ditetapkan berdasarkan ketentuan setiap item angket diwakili oleh 10 responden. Namun, berdasarkan data pengisian angket diperoleh 270 yang mengisi lengkap. Anggota sampel penelitian secara rinci disajikan pada Tabel 1.

Teknik pengumpulan data menggunakan Skala Anteseden Kearifan Konselor yang dikembangkan sendiri oleh peneliti. Skala ini mengukur 28 faktor yang mempengaruhi kearifan konselor. Skala ini berbentuk skala rating dengan lima jenjang, yaitu: 1 $=$ sangat tidak relevan, $2=$ tidak relevan, 3 $=$ cukup relevan, $4=$ relevan, dan $5=$ sangat relevan. 
Tabel 1. Sampel Penelitian

\begin{tabular}{clc}
\hline No & Program Studi BK & Sampel \\
\hline 1 & Universitas Negeri Semarang & 39 \\
2 & Universitas Negeri Yogyakarta & 43 \\
3 & Universitas Negeri Malang & 48 \\
4 & Universitas Negeri Jakarta & 24 \\
5 & Universitas Negeri Makassar & 3 \\
6 & Universitas Pendidikan Ganesha & 2 \\
7 & Universitas Prof. Dr. Hamka & 24 \\
8 & Universitas Ahmad Dahlan & 60 \\
9 & Universitas Katolik Atmajaya & 11 \\
10 & Universitas Kristen Indonesia & 1 \\
11 & Universitas Sanata Dharma & 15 \\
\hline
\end{tabular}

Teknik analisis data menggunakan statistik deskriptif dan analisis faktor eksploratoris. Secara operasional, analisis data menggunakan perangkat lunak IBM SPSS $v$. 20.0 for windows.

\section{Hasil Penelitian dan Pembahasan}

Hasil penelitian seperti yang tertera pada Tabel 2. menunjukkan terdapat 28 faktor yang mempengaruhi kearifan menurut perspektif calon konselor etnis Jawa dengan skor rata-rata terentang dari 2,9-4,6 dalam skala 1-5. Calon konselor etnis Jawa menilai 17 faktor sangat relevan untuk mengembangkan kearifan dengan skor rata-rata terentang dari 4,1 - 4,6. Ketujuh belas faktor yang dimaksud secara berturut-turut dari skor rata-rata tertinggi ke terendah, yaitu: kepribadian, motivasi, pengalaman konseling, timbangan moral, interaksi sosial, kecerdasan, pandangan hidup, pelatihan profesional, kompetensi konseling, hasil belajar melalui pengalaman, pengalaman hidup, pengalaman belajar dari orang yang arif (pendidik konselor, mentor, model peran, orang tua), hasil internalisasi, integrasi, dan refleksi pengalaman), agama, orientasi nilai, tingkat pendidikan, dan pengalaman belajar melalui teknik kesadaran diri.

Calon konselor etnis Jawa menilai 10 faktor relevan dalam mempengaruhi perkembangan kearifan konselor dengan skor ratarata terentang dari 3,1-4,0. Faktor-faktor yang dimaksud secara berturut-turut dari skor rata-rata tertinggi ke terendah, yaitu: lembaga pendidikan, pendidikan, pengalaman belajar menghadapi ketidakpastian, pengalaman belajar menggunakan metode Dialog Socratic, keterampilan berpikir dialektik, pengalaman latihan meditasi, usia, pengalaman belajar filsafat, bimbingan spiritual secara bertahap (misalnya tradisi Sufi), etnis, dan jenis kelamin. Sementara itu, pengalaman menghadiri upacara kematian dinilai cukup relevan sebagai faktor yang mempengaruhi kearifan konselor menurut perspektif calon konselor etnis Jawa dengan skor ratarata 2,9 .

Tabel 2. Faktor-faktor yang Mempengaruhi Kearifan Konselor

\begin{tabular}{llll}
\hline No Faktor & $M$ & $S D$ \\
\hline 1 & Kepribadian & 4,6 & 0,6 \\
2 & Motivasi & 4,5 & 0,7 \\
3 & Pengalaman konseling & 4,5 & 0,7 \\
4 & Timbangan moral & 4,4 & 0,7 \\
5 & Interaksi sosial & 4,4 & 0,7 \\
6 & Kecerdasan & 4,3 & 0,8 \\
7 Pandangan hidup & 4,3 & 0,7 \\
8 & Pelatihan profesional & 4,3 & 0,8 \\
9 & Kompetensi konseling & 4,3 & 0,8 \\
10 & Hasil belajar berbasis pengalaman (ELT) & 4,3 & 0,7 \\
11 & Pengalaman hidup & 4,3 & 0,7 \\
12 & Pengalaman belajar dari orang yang arif & 4,3 & 0,7 \\
13 Hasil internalisasi, integrasi, refleksi & 4,3 & 0,7 \\
pengalaman & & \\
14 & Agama & 4,2 & 0,8 \\
15 & Orientasi nilai & 4,2 & 0,8 \\
16 & Tingkat pendidikan & 4,2 & 0,8 \\
17 & Pengalaman belajar melalui teknik & 4.1 & 0,7 \\
kesadaran diri & & \\
18 Lembaga pendidikan & 4,0 & 0,9 \\
19 & Pengalaman menghadapi ketidakpastian & 3,9 & 0,8 \\
20 & Pengalaman belajar menggunakan & 3,8 & 0,8 \\
metode Dialog Socratic & & \\
21 & Keterampilan berpikir dialektik & 3,7 & 0,8 \\
22 & Pengalaman dari latihan meditasi & 3,7 & 0,9 \\
23 & Usia & 3,6 & 0,9 \\
24 & Pengalaman belajar filsafat & 3,6 & 0,9 \\
25 & Pengalaman bimbingan spiritual & 3,5 & 1,0 \\
26 & Etnis & 3,4 & 1,1 \\
27 & 3,1 & 1,1 \\
& 2,9 & 1,2 \\
& & \\
\hline
\end{tabular}


Hasil analisis faktor eksploratoris menggunakan IBM SPSS version 20.0 for Windows diperoleh nilai KMO sebesar 0,875. Uji Bartlett's Test of Sphericity menghasilkan perkiraan Chi-Square sebesar 2945,75 dengan Sig. $(0,000)<p(0,05)$. Hasil pengujian juga menunjukkan nilai Measure of Sampling Adequacy (MS A) pada tabel Anti-Image Matrices terentang dari 0,815 - 0,939 >0,05 Artinya, variabel dan sampel (faktor-faktor yang mempengaruhi kearifan konselor menurut perspektif calon konselor etnis Jawa) yang digunakan memungkinkan untuk dilakukan analisis selanjutnya.

Penentuan jumlah faktor yang mungkin terbentuk dilakukan dengan melihat tabel Total Variance Explained. Hasil pengujian menunjukkan dari 28 faktor yang diteliti diperoleh enam faktor yang mungkin terbentuk yaitu faktor dengan nilai Eigenvalues
$>$ 1. Varians yang dapat diterangkan oleh faktor 1 sebesar 28,767\%, faktor 2 sebesar $9,022 \%$, faktor 3 sebesar $6,722 \%$, faktor 4 sebesar 5,336\%, faktor 5 sebesar 4,320\%, dan faktor 6 sebesar 3,977\%. Total keenam faktor ini akan mampu menjelaskan variabel (memprediksi kearifan konselor) sebesar $58,144 \%$.

Hasil analisis faktor eksploratoris menggunakan metode ekstraksi principal component analysis dan metode rotasi varimax with kaizer normalization menunjukkan faktor yang mungkin terbentuk maksimal enam. Penentuan setiap variabel yang akan masuk ke faktor 1, faktor 2, faktor 3, faktor 4, faktor 5, atau faktor 6 dilakukan dengan cara melihat besaran nilai korelasi antara variabel dengan faktor dalam tabel Rotated Component Matrix. Hasil pengujian secara rinci disajikan pada Tabel 3.

Tabel 3. Rorated Componen Matrix

\begin{tabular}{|c|c|c|c|c|c|c|}
\hline & \multicolumn{6}{|c|}{ Komponen } \\
\hline & 1 & 2 & 3 & 4 & 5 & 6 \\
\hline Motivasi & 0,732 & & & & & \\
\hline Pandangan hidup & 0,704 & & & & & \\
\hline Orientasi nilai & 0,696 & & & & & \\
\hline Kepribadian & 0,691 & & & & & \\
\hline Timbangan moral & 0,602 & & & & & \\
\hline Interaksi social & & 0,727 & & & & \\
\hline Pengalaman hidup & & 0,704 & & & & \\
\hline Hasil internalisasi, integrasi, refleksi pengalaman & 0,365 & 0,574 & & & & \\
\hline Pengalaman belajar dari orang yang arif & & 0,539 & & & 0,370 & \\
\hline Pengalaman menghadapi ketidakpastian & & 0,537 & & 0,346 & & \\
\hline Pengalaman belajar melalui teknik kesadaran diri & & 0,496 & & & & \\
\hline Pengalaman latihan meditasi & & 0,487 & & 0,452 & & $-0,343$ \\
\hline Hasil belajar berbasis pengalaman (ELT) & & 0,484 & & & & \\
\hline Pengalaman belajar menggunakan metode Dialog Socratic & & 0,358 & & 0,348 & & \\
\hline Jenis kelamin & & & 0,771 & & & \\
\hline Usia & & & 0,734 & & & \\
\hline Etnis & & & 0,640 & & & \\
\hline Pengalaman menghadiri ucapara kematian & & & 0,549 & 0,422 & & \\
\hline Agama & 0,383 & & 0,468 & & & \\
\hline Pengalaman bimbingan spiritual & & 0,384 & 0,446 & 0,426 & & \\
\hline Pengalaman belajar filsafat & & & & 0,742 & & \\
\hline Keterampilan berpikir dialektik & & & & 0,729 & & \\
\hline Pelatihan profesional & & & & & 0,753 & \\
\hline Lembaga pendidikan & & & 0,338 & & 0,637 & \\
\hline Kecerdasan & 0,397 & & & & 0,555 & \\
\hline Tingkat pendidikan & & & 0,409 & & 0,441 & 0,396 \\
\hline Kompetensi konseling & & & & & & 0,703 \\
\hline Pengalaman konseling & & & & & 0,349 & 0,696 \\
\hline
\end{tabular}


Berdasarkan Tabel 3 diketahui bahwa enam faktor yang mempengaruhi kearifan konselor menurut perspektif calon konselor etnis Jawa adalah sebagai berikut.

Faktor 1, terdiri atas: motivasi, pandangan hidup, orientasi nilai, kepribadian, timbangan moral, dan kecerdasan. Faktor 1 ini dinamakan faktor kepribadian dan kecerdasan.

Faktor 2, terdiri atas: pengalaman interaksi sosial, pengalaman hidup, (internalisasi, intergrasi, dan refleksi pengalaman), pengalamanbelajar dari orang yang arif (pendidik konselor, konselor, mentor, model peran, dan orang tua), pengalaman menghadapi ketidakpastian, pengalaman belajar melalui teknik kesadaran diri, belajar berbasis pengalaman (the experiential learning), pengalaman latihan meditasi, dan pengalaman belajar menggunakan metode Dialog Socratic. Faktor 2 ini dinamakan faktor pengalaman.

Faktor 3, terdiri atas: jenis kelamin, usia, agama, pengalaman menghadiri upacara kematian, pengalaman bimbingan spiritual secara bertahap (misalnya tradisi Sufi). Faktor 3 ini dinamakan faktor atribut pribadi, agama, dan spiritual.

Faktor 4, terdiri atas: pengalaman belajar filsafat dan keterampilan berpikir dialektik. Faktor 4 ini dinamakan faktor keterampilan metakognitif (berpikir kritis dan mendalam).

Faktor 5, terdiri atas: pelatihan profesional, lembaga pendidikan, tingkat pendidikan. Faktor 5 ini dinamakan faktor konteks fasilitatif.

Faktor 6, terdiri atas: kompetensi konseling dan pengalaman konseling. Faktor 6 ini dinamakan faktor kepakaran (profesionalitas).

Berdasarkan korelasi antarvariabel yang disajikan pada tabel Component Transformation Matrix, dapat dismpulkan bahwa keenam tepat untuk merangkum faktor-faktor yang mempengaruhi kearifan karena korelasinya $>p(0,05)$. Hal ini ditunjukkan oleh korelasi faktor $1(0,508)$, faktor $2(-0,232)$, faktor $3(-0,157)$, faktor $4(0,456)$, faktor 5 $(0,494)$, dan faktor $6(0,199)$.
Faktor-faktor yang mempengaruhi kearifan konselor menurut perspektif calon konselor etnis Jawa seperti yang tertera pada Tabel 2 dan Tabel 3, yaitu: (1) kepribadian dan kecerdasan, (2) pengalaman, (3) atribut pribadi, agama, dan spiritual, (4) keterampilan metakognitif, (5) konteks fasilitatif, dan (6) kepakaran (profesionalitas). Hasil penelitian dan pembahasannya disajikan berikut.

Faktor 1 yaitu Kepribadian dan Kecerdasan. Hasil penelitian menunjukkan bahwa $28,767 \%$ faktor kepribadian dan kecerdasan berkontribusi terhadap perkembangan kearifan konselor menurut perspektif calon konselor etnis Jawa. Para pakar dan peneliti terdahulu berpendapat bahwa kepribadian dan kecerdasan berperan penting sebagai faktor ontogenesis/prediktor kearifan, baik wisdom-related knowledge maupun wisdom-related performance (Staudinger, 1999, p. 648). Hasil penelitian Baltes \& Staudinger (2000, p. 130) menunjukkan: (1) $15 \%$ faktor kecerdasan, 21\% kepribadian, dan 35\% kecerdasan dan kepribadian mempengaruhi kearifan. Penelitian Sternberg (1986, p. 178) juga menemukan korelasi yang positif signifikan pada kategori medium $(r=0,68)$ antara kecerdasan dan kearifan.

Kunzmann \& Baltes (2003, p. 1112) dalam penelitiannya menemukan bahwa faktor kepribadian (afektif, orientasi nilai, mautivasional, dan antarpribadi) dan kecerdasan berkorelasi positif dengan wisdomrelated knowledge. Hasil Penelitian lainnya juga menemukan bahwa dimensi kepribadian (keterbukaan terhadap pengalaman) berkontribusi dan menjadi prediktor kearifan, terutama wisdom-related knowledge dan timbangan (Staudinger, Dorner, \& Mickler, 2005, p. 198; Mickler \& Staudinger, 2008 p. 792793).

Faktor 2 yaitu Pengalaman. Hasil penelitian menunjukkan bahwa 9,022\% faktor pengalaman berkontribusi terhadap perkembangan kearifan konselor menurut perspektif calon konselor etnis Jawa. Hasil penelitian ini relevan dengan pendapat para pakar dan temuan penelitian terdahulu. Perkembangan kearifan memerlukan transendensi dan proyeksi yang dapat diperoleh melalui 
kesadaran diri, pengujian diri, serta refleksi terhadap perilaku, interaksi, dan pengalaman sepanjang rentang kehidupan (Ardelt, 2010, p. 202; Brown, 2004, p. 140; Levitt, 1999, p. 94; Staudinger, 1999, p. 650). Penelitian lainnya menemukan faktor kunci yang memengaruhi perkembangan kearifan, yaitu belajar dari pengalaman melalui refleksi, integrasi, dan transformasi pengalaman (Brown, 2004, pp. 139-140).

Agar menjadi konselor multibudaya yang arif, calon konselor multibudaya perlu diberi kesempatan untuk merefleksi, bertanya, menginternalisasikan, dan mengintegrasikan pengalaman-pengalaman pribadi dan profesionalnya (Hanna, Bemak, \& Chung, 1999, p. 131). Akumulasi pengalaman hidup juga tidak secara otomatis dapat mengembangkan kearifan calon konselor multibudaya seiring bertambahnya usia. Kearifan bergantung pada kemampuan calon konselor multibudaya untuk mengintegrasikan dan me-refleksikan pengalaman sepanjang hayat dan memanfaatkan pengalaman tersebut dalam kehidupan sehari-hari (Baltes \& Staudinger, 2000, p. 128-129) serta memanfaatkannya dalam praktik konseling multibudaya.

Faktor 3 yaitu Atribut Pribadi, Agama, dan Spiritual. Hasil penelitian menunjukkan bahwa $6,722 \%$ faktor atribut pribadi (usia dan jenis kelamin), agama, dan spiritual berkontribusi terhadap kearifan menurut perspektif calon konselor etnis Jawa. Faktor ini menarik untuk dikaji karena banyak kontroversial di antara para pakar dan peneliti.

Usia dan kearifan. Kajian tentang usia dan kearifan penuh dengan kontroversial. Sebagian pakar dan peneliti mengatakan usia mempengaruhi kearifan, sedangkan yang lainnya berpandangan sebaliknya. Sebagian pakar dan peneliti terdahulu berargumen bahwa usia tua tidak menjamin seseorang menjadi arif (Baltes \& Staudinger, 2000, p. 130; Staudinger \& Gluck, 2011, p. 219; Sternberg, 2005c, p. 5) dan usia tidak berhubungan dengan kriteria dasar kearifan (Mickler \& Staudinger, 2008, p. 790). Meskipun kearifan sebagai prototipe keberhasil- an dan virtue puncak perkembangan di masa tua, tetapi sebenarnya tidak otomatis dapat dicapai oleh setiap orang dewasa (Parisi et al., 2009, p. 869) bahkan faktanya fluid intelligence menurun seiring dengan bertambahnya usia sehingga menghambat kemampuan pemecahan masalah dan penalaran serta bertentangan dengan kearifan. Sementara itu, pakar lainnya berpendapat dan menemukan bahwa usia berhubungan dengan kearifan. Penelitian Ardelt (2010, pp. 200-201) menemukan bahwa orang dewasa yang lebih tua yang berpendidikan perguruan tinggi secara signifikan cenderung memiliki kearifan pada dimensi reflektif dan afektif yang lebih tinggi daripada mahasiswa. Bukti kualitatif juga menunjukkan $20 \%$ orang dewasa yang lebih tua menjadi lebih arif seiring bertambahnya usia dengan belajar dari pengalaman hidup. Artinya, kearifan dapat meningkat seiring bertambahnya usia bagi individu yang memiliki peluang dan motivasi untuk mencapai perkembangannya. Penelitian Webster, Esterhof, \& Bohlmeijer (2012, pp. 212-214) menemukan bahwa orang dewasa madya lebih arif daripada orang dewasa muda. Hal ini beralasan karena crystallized intelligence berkembang seiring pertambahan usia. Penelitian cross-sectional yang dilakukan oleh Asadi, Amiri, Molavi, \& Noaparast (2012, p. 485) menunjukkan bahwa terdapat perbedaan yang signifikan kearifan, khususnya dimensi reflektif dan afektif pada lima kelompok usia partisipan.

Berdasarkan pro-kontra tersebut, Jordan (2005 pp. 161-162) mengemukakan tiga model kearifan dan penuaan; (1) model positif yang mengatakan bahwa kearifan meningkat seiring bertambahnya usia; (2) model penurunan yang mengasumsikan bahwa kearifan menurun setelah individu mencapai usia dewasa muda; (3) model terkristal yang mengusulkan bahwa kearifan diperoleh selama masa remaja dan dewasa muda, namun setelah itu relatif stabil dan tetap. Model terakhir mengisyaratkan bahwa pengalaman hidup tidak berkaitan langsung dengan pencapaian kearifan.

Jenis kelamin dan kearifan. Jenis kelamin dipandang sebagai salah satu faktor konteks 
fasilitatif yang cukup relevan untuk mengembangkan kearifan menurut perspektif calon konselor Indonesia. Hasil penelitian ini relevan dengan penelitian sebelumnya yang secara umum menunjukkan bahwa perbedaan jenis kelamin dalam konsepsi kearifan cenderung rendah. Penelitian Hollingworth, Escobedo, Graudina, Misiuniene, \& Park (2013, pp. 222-223) menemukan 52\% variasi kearifan dipengaruhi oleh jenis kelamin. Pada laki-laki, 34.7\% variasi kearifan dijelaskan oleh empat faktor utama, yaitu Kepribadian, tanggung jawab, orientasi tujuan, dan tidak konvensional. Sementara itu, Pada perempuan, $38.3 \%$ variasi kearifan dijelaskan oleh empat faktor, yaitu Pengaruh sosial, tanggung jawab, pencapaian tujuan, dan tidak konvensional.

Agama, spiritual, dan kearifan. Kajian meta-analisis menemukan bahwa agama merupakan salah satu faktor konteks-fasilitatif yang mempengaruhi kearifan (Kunzmann \& Baltes, 2005, p. 120). Hasil penelitian Chen, Wu, Cheng, \& Hsueh (2011, p. 181) juga menunjukkan bahwa agama merupakan salah satu dari delapan faktor fasilitatif yang mempengaruhi perkembangan kearifan menurut perspektif pendidik yang dinominasikan memiliki kearifan. Selain itu, agama juga diidentifikasi sebagai salah satu sumber konsep kearifan dan karakteristik orang arif.

Penelitian yang dilakukan oleh Ferrari, Kahn, Benayon, \& Nero (2011, pp. 128142) menemukan perbedaan kearifan orang Islam dan Yahudi. Orang Islam memiliki kearifan sophia (mencintai kearifan namun masih sebatas teori) yang lebih menonjol, sedangkan orang Yahudi lebih menonjol pada phronesis (mencintai kearifan dan menampilkannya dalam praktik kehidupan seharihari). Jika dianalisis berdasarkan usia diperoleh hasil berikut. Pertama, anak perempuan Yahudi (usia 10 tahun) dan anak laki-laki (11 tahun) Muslim memiliki skor kearifan yang lebih daripada anak di kelompok lain seusianya. Kedua, remaja Yahudi (usia 17.5 tahun) memiliki skor kearifan yang lebih tinggi daripada remaja Muslim (usia 18 tahun). Ketiga, pendidik Yahudi (usia 65 tahun) memiliki skor kearifan yang lebih ting- gi daripada orang dewasa Muslim (usia 65 tahun). Keempat, anak-anak Yahudi memiliki skor sopbia yang lebih tinggi daripada anak-anak Muslim. Kelima, remaja Yahudi dan Muslim memiliki skor yang sama-sama tinggi pada sophia. Terakhir, orang dewasa Yahudi memiliki skor sophia lebih tinggi daripada orang dewas Muslim.

Faktor 4 yaitu Keterampilan Metakognitif. Hasil penelitian menunjukkan bahwa $5.336 \%$ faktor keterampilan metakognitif (berpikir kritis dan mendalam) merupakan salah satu yang berkontribusi terhadap perkembangan kearifan konselor menurut perspektif calon konselor etnis Jawa. Pakar dan peneliti terdahulu mengganggap bahwa keterampilan metakognitif sebagai salah satu komponen utama kearifan. Konselor multibudaya dengan keterampilan metakognitif akan memiliki "kepedulian terhadap keterbatasan dan perkiraan pengetahuan, kesadaran akan kesadaran, mengetahui tentang mengetahui, berpikir tentang berpikir, dan pengetahuan intuitif' (Hanna and Ottens, 1995, p. 199; Hanna, Bemak, \& Chung, 1999, p. 127).

Keterampilan metakognisi ditandai juga oleh keterampilan berpikir kritis yang berhubungan langsung dengan kearifan (Barris \& Ruff, 2010, p. 5). Keterampilan metakognisi merupakan keterampilan berpikir tingkat tinggi. Menurut Brookhart (Kurniati, Harimukti, \& Jamil, 2016, p. 143) "keterampilan berpikir tingkat tinggi (HOTS), meliputi: kemampuan logika dan penalaran (logic and reasoning), analisis (analysis), evaluasi (evaluation), pemecahan masalah (problem-solving), dan timbangan (judgement)."

Faktor 5 yaitu Konteks Fasilitatif. Hasil penelitian menunjukkan bahwa $4.320 \%$ faktor konteks fasilitatif (pelatihan profesional, lembaga pendidikan, tingkat pendidikan) berkontribusi terhadap perkembangan kearifan konselor menurut perspektif calon konselor etnis Jawa. Hasil penelitian ini relevan dengan pendapat pakar dan temuan empirik terdahulu bahwa salah satu faktor konteks fasilitatif yang mempengaruhi kearifan yaitu pendidikan dan pelatihan profesional (Baltes, Gluck, \& Kunzmann, 2005, 
p. 332; Baltes \& Staudinger, 2000, p. 125; Chen et al., 2011, p. 179; Staudinger, 1999, p. 646). Pendidikan dan/atau pengalaman memiliki peran strategis dalam mengembangkan kearifan (Frantz, 2014, p. 2). Pakar lainnya (Brown, 2004, p. 139-141) mengusulkan dan menemukan cara mengembangkan kearifan di kampus, yaitu melalui praktik, refleksi, dan integrasi pengalaman praktik. Hal ini dapat dilakukan dengan menciptakan empat kondisi fasilitatif bagi pengembangan kearifan, yaitu: orientasi terhadap belajar, pengalaman, interaksi dengan orang lain, dan lingkungan yang kondusif. Bahkan Sternberg (2001, pp. 240-242) dan Sternberg, Jarvin, \& Reznitskaya (2008, pp. 43-53) mengusulkan pentingnya merancang dan menerapkan kurikulum infused untuk mengembangkan kearifan peserta didik.

Parisi et al. (2009, p. 670) mengajukan hipotesis Experience Corps sebagai model untuk mengembangkan kearifan antargenerasi, yaitu melalui pengalaman, interaksi sosial, generativitas, dan modal sosial. Kearifan dapat diaktifkan atau ditingkatkan melalui refleksi dan dialektis dalam interaksi antargenerasi - pendidik konselor dan calon konselor. Melalaui mentorship, pendidik konselor dapat merumuskan solusi alternatif dan menarik untuk merefleksikan pengetahuan dan pengalaman sebelumnya sehingga mampu mempertimbangkan kompleksitas kehidupan dengan cara yang lebih komprehensif dan bermakna. Pendidik konselor dapat menjadi model peran cara berpikir reflektif dan arif. Jika kearifan berkembang dan dapat dikembangkan sepajang rentang kehidupan, terdapat kemungkinan pengalaman awal kehidupan akan membantu dalam mengembangkan kualitas kearifan.

Faktor 6 yaitu Kepakaran (Profesionalitas). Hasil penelitian menunjukkan bahwa $3.977 \%$ faktor kepakaran (profesionalitas) berkontribusi terhadap perkembangan kearifan konselor menurut perspektif calon konselor etnis Jawa. Kajian pakar dan temuan empirik terdahulu juga menunjukkan bahwa faktor kepakaran seperti pengalaman praktik berkelanjutan (Baltes \& Kunzmann, 2005b, p. 120) berpengaruh terhadap kearif- an. Penelitian yang dilakukan oleh Phan et al. (2009, p. 159) menemukan 14\% kompetensi (kepakaran) konseling multibudaya calon konselor yang mengikuti program pendidikan konselor dipengaruhi oleh kearifan dirinya sendiri.

Temuan penelitian ini relevan dengan penelitian sebelumnya bahwa terdapat banyak faktor yang mempengaruhi kearifan. Hasil penelitian Chen et al. (2011, pp. 177181) menemukan delapan faktor fasilitatif yang mempengaruhi kearifan menurut perspektif pendidik yang dinominasikan memiliki kearifan, yaitu: (1) pengalaman kerja, (2) pengalaman hidup, (3) interaksi sosial, (4) pengamatan, (5) pendidikan di keluarga, (6) pengembangan profesional, (7) agama, dan (8) membaca. Selain itu, penelitian ini juga menemukan bahwa proses perkembangan perkembangan kearifan menurut perspektif pendidik yang dinominasikan memiliki kearifan dipengaruhi oleh, yaitu: (1) kondisi fasilitatif, (2) asimilasi dan penyesuaian dari dalam, (3) transformasi tindakan aktual, dan (4) umpan balik dari hasil tindakan aktual.

Hasil kajian meta-analisis yang dilakukan oleh Baltes, Gluck, \& Kunzmann (2005, p. 332) menemukan tiga domain dan kondisi ontogenesis yang mempengaruhi perkembangan kearifan, yaitu: "Pertama, faktor konteks pengalaman fasilitatif, seper-ti: usia, pendidikan, profesi, dan pengasuhan orang tua; Kedua, faktor kepakaran, seperti: pengalaman hidup, mentorship, dan motivasional; Terakhir, faktor pribadi, seperti: kecerdasan, kreativitas, emosional, dan kepribadian. Hasil penelitian Staudinger (1999 p. 646) dan Baltes \& Staudinger (2000, p. 125) menemukan tiga kelompok faktor/anteseden yang mempengaruhi kearifan, khususnya wisdom-related knowlegde and skills, yaitu Pertama, faktor pribadi secara umum, meliputi: mekanisme kognitif, kesehatan mental, gaya kognitif, kreativitas, keterbukaan terhadap pengalaman, dan kekuatan ego. Kedua, faktor kepakaran spesifik, meliputi: pengalaman dalam pola-pola kehidupan, pengawasan terorganisasi, mentorship dalam mengatasi masalah hidup, heuristik kognitif, 
dan disposisi motivasional. Terakhir, faktor konteks pengalaman fasilitatif, mencakup: usia, pendidikan, pengasuhan orang tua, mendapatkan mentorship, konteks profesi/ pekerjaan, periode historis.

Hasil kajian meta-analisis yang dilakukan oleh Baltes \& Staudinger (2000, p. 130) menunjukkan empat faktor yang mempengaruhi kearifan, khususnya wisdom-related performance pada orang dewasa yang dinominasikan sebagai orang yang arif, yaitu: Pertama, 35\% variabilitas kearifan dipengaruhi oleh kepribadian-kecerdasan, seperti: kreativitas, gaya kognitif, dan kecerdasan sosial. Kedua, 26\% variabilitas kearifan dipengaruhi oleh pengalaman hidup, baik pengalaman hidup secara umum maupun pengalaman profesional spesifik. Ketiga, 21\% variabilitas kearifan dipengaruhi oleh ciri-ciri kepribadian, seperti: keterbukaan terhadap pengalaman, pertumbuhan pribadi, dan keterbukan psikologis. Keempat, 15\% variabilitas kearifan dipengaruhi oleh kecerdasan, baik kecerdasan fluid maupun crystallized. Sementara itu, usia tidak dianggap sebagai faktor yang mempengaruhi kearifan. Hasil penelitian ini dapat disimpulkan bahwa kearifan berkembang secara dinamis melalui faktor kepribadian, kecerdasan, dan pengalaman daripada melalui usia.

Hasil penelitian Orwoll \& Perlmutter (1990, p. 170) menunjukkan $78 \%$ partisipan orang dewasa yang dinominasikan arif menilai kearifannya dipengaruhi oleh usia, 16\% oleh jenis kelamin, dan 68\% oleh pendidikan. Kearifan berkembang seiring dengan pertambahan usia, terutama sampai usia 40 tahun dan setelah itu mengalami penurunan. Partisipan laki-laki lebih suka menominasikan orang yang arif dari jenis kelamin lakilaki, begitupun sebaliknya. Ditinjau dari pendidikan, partisipan menominasikan orang yang berpendidikan tinggi dianggap lebih arif dibandingkan dengan yang berpendidikan rendah.

\section{Simpulan}

Penelitian ini telah menghasilkan faktor-faktor yang mempengaruhi kearifan konselor menurut perspektif calon konselor etnis Jawa. Hasil analisis faktor eksploratoris diperoleh enam faktor yang mempengaruhi kearifan konselor menurut perspektif calon konselor etnis Jawa, yaitu (1) kepribadian dan kecerdasan, (2) pengalaman, (3) pribadi, agama, dan spiritual; (4) kecakapan metakognitif (berpikir kritis dan mendalam); (5) konteks fasilitatif; dan (6) kepakaran (profesionalitas).

Saran penelitian ditujukan kepada berbagai pihak yang terkait. Pertama, calon konselor diharapkan dapat mengembangkan kearifan pribadi dengan cara: (1) mematangkan kepribadian yang terintegritas dan sehat, serta mengoptimalkan kecerdasan, (2) belajar dari pengalaman pribadi dan orang arif (misanya pendidik konselor, konselor, mentor, model peran, dan orang tua yang arif); (3) mempelajari keberagaman budaya, mengamalkan nilai-nilai agama dan spiritualitas; (4) belajar dan berlatih mengoptimalkan kecakapan metakognitif (misalnya mempelajari filsafat dan belajar berpikir dialektik); dan (5) mengikuti pendidikan dan pelatihan berbasis pengalaman otentik untuk meningkatkan kepakaran (profesionalitas) dalam konseling.

Kedua, pendidik konselor di Program Studi BK dan pengurus Asosiasi Bimbingan dan Konseling Indonesia (ABKIN) diharapkan dapat menyediakan program pendidikan konselor (PPK) yang fasilitatif bagi pengembangan kearifan calon konselor. Program pendidikan konselor yang dimaksud, meliputi: (1) konten kurikulum mengandung muatan pengembangan kearifan, baik khusus pada mata kuliah pengembangan kepribadian maupun terintegrasi pada setiap mata kuliah; (2) strategi pembelajaran dapat menggunakan model pembelajaran berbasis pengalaman dalam adegan otentik, belajar melalui metode Dialog Socratic, belajar melalui teknik kesadaran diri, latihan meditasi, bimbingan spiritual secara bertahap (misalnya tradisi Sufi); (3) evaluasi pembelajaran berbasis asesmen otentik; dan (4) pendidik konselor menampilkan diri sebagai pribadi dan konselor yang arif bagi calon konselor, baik dalam proses pembelajaran maupun dalam kehidupan sehari-hari. 
Ketiga, peneliti selanjutnya diharapkan dapat mengkaji faktor-faktor yang mempengaruhi kearifan menurut calon konselor dan konselor dari berbagai etnis di Indonesia, mengkaji berbagai variabel anteseden dan konsekuensi kearifan konselor, serta mengembangkan dan menguji berbagai strategi pembelajaran untuk mengembangkan kearifan calon konselor.

\section{Daftar Pustaka}

Ardelt, M. (2000a). Intellectual versus wisdom-related knowledgep. The case for a different kind of learning in the later years of life. Educational Gerontology, 26, 771-789.

Ardelt, M. (2000b). Antecedents and effects of wisdom in old agep. A longitudinal perspective on aging well. Research on Aging, 22(4), 360-394.

Ardelt, M. (2003). Empirical assessment of a three-dimensional wisdom scale. Research on Aging, 23(3), 275-324.

Ardelt, M. (2004). Wisdom as expert knowledge systemp. A critical review of a contemporary operationalization of an Ancient concept. Human Development, 47(1), 257-285.

Ardelt, M. (2010). Are older adults wiser than college students? A comparison of two age cohorts. Journal of Adult Development, 17(4), 193-207.

Ardelt, M. (2011). The measurement of wisdomp. A commentary on Taylor, Bates, and Webster's comparison of the SAWS and 3D-WS. Journal of Experimental and Aging Research, 37(2), 241-255.

Arlin, P. K. (1990). The art of problem finding. In R.J. Sternberg (Eds.). Wisdomp. Its nature, origins, and development (pp. 230243). Cambridgep. Cambridge University Press.

Asadi, S., Amiri, S., Molavi, H. \& Noaparast, K.B., (2012). A crosssectional study of self reported wisdom developmentp. From adolescence through adulthood. Interdisciplinary Journal of Contemporary Research Business, 4(2), 482-92.
Baltes, P. B., Gluck, J., \& Kunzmann, U. (2005). Wisdomp. its structure and function in regulating successful life-span development. In C.R. Snyder, S.J. Lopez (Eds.). Handbook of positive psychology (pp. 327347). Oxfordp. Oxford University Press.

Baltes, P. B., \& Staudinger, U. M. (2000). Wisdomp. A metaheuristic (pragmatic) to orchestrate mind and virtue toward exellence. American Psychologist, 55(1), 123-124.

Barris, J., \& Ruff, J. C. C. (2010). Thoughts on wisdom and its relation to critical thinking, multiculturalism, and global awareness. Analytic Teaching and Philosophical Praxis, 31(1), 5-20.

Chen, L-M., Wu, P-J., Cheng, Y-Y., Hsueh, H-I. (2011). A qualitative inquiry of wisdom developmentp. Educator's perspectives. International Journal of Aging and Human Development, 72(3), 171-187.

Ferrari, M., Kahn, A., Benayon, M., \& Nero, J. (2011). Phronesis, sophia, and hochmap. Developing wisdom in Islam and Judaism. Research in Human Development, 8(2), 128-148.

Frantz, G. (2014). Wisdom: Experience or education? Psychological Perspectives, 1-3.

Gluck, J., \& Bluck, S. (2011). Laypeople's conceptions of wisdom and its developmentp. Cognitive and integrative views. Psychological Sciences, 1-4.

Hanna, F. J., Bemak, F., \& Chung, R. C. Y. (1999). Toward a new paradigm of multicultural counseling. Journal of Counseling and Development, 77(2), 125134.

Hanna, F. J., \& Ottens, A. J. (1995). The role of wisdom in psychotherapy. Journal of Psychotherapy Integration, 5(3) 195-219.

Heppner, P.P., Wampold, B.E., \& Kivlighan, D.M. (2008). Research design in counseling (3rd Edition). USAp. Thomson \& Brooks/Cole.

Hollingworth, L., Escobedo, P.S, Graudina, L., Misiuniene, J., \& Park, K. (2013). 
Gender difference on the concept of widomp. An international comparison. Gifted and Talented International, 28(2), 219-225.

Jeste, D. V., Ardelt, M., Blazer, D., Kraemer, H. C., Vaillant, G., \& Meeks, T. W. (2010). Expert consensus on characteristics of wisdomp. A delphi method study. Gerontologist, 50(5), 668680.

Jones, W. E. (2015). Wisdom as an aim of higher education. Journal of $V$ alue Inquiry, 49(1), 1-15.

Karelitz, T. M., Jarvin, L., \& Sternberg, R. J. (2010). The meaning of wisdom and its development throught life. In R.M. Lerner \& W.F. Overton (Eds.). The handbook of life-span developmentp. Cognition, biology, methods (pp. 838-875). Hoboken, New Jerseyp. John Willey \& Sons. Inc.

Kunzmann, U., \& Baltes, P. B. (2003). Wisdom-related knowledgep. Affective, motivational, and interpersonal correlates. Personality and Social Psychology Bulletin, 29(1), 11041119.

Kunzmann, U., \& Baltes, P. B. (2005). The psychology of wisdomp. Theoretical and empirical challanges. In R.J. Sternberg \& J. Jordan (Eds.). A handbook of wisdomp. Psychological perspectives (pp. 110-135). New Yorkp. Cambridge University Press.

Kurniati, D., Harimukti, R., \& Jamil, N. A. (2016). Kemampuan berpikir tingkat tinggi siswa SMP di kabupaten jember dalam menyelesaikan soal berstandar PISA. Jurnal Penelitian Dan Evaluasi Pendidikan, 20(2), 142-155. https://doi.org/10.21831/pep.v20i2.8 058

Levitt, H. M. (1999). The development of wisdomp. An analysist of Tibetian Buddhist's experience. Journal of Humanistic Psychology, 39(2), 86-105.

Levitt, H. M., \& Piazza-Bonin, E. (2016). Wisdom and psychotherapyp. Studying expert therapist' clinical wisdom to explicate common process. Psychotherapy Research, 31-47.
Marshall, A., \& Thorburn, M. (2014). Cultivating practical wisdom as education. Educational Philosophy and Theory, 46(14), 1541-1553. https://doi.org/10.1080/00131857.20 13.856280

Mickler, C., \& Staudinger, U. M. (2008). Personal wisdomp. Validation and agerelated differences of a performance measure. Psychology and Aging, 23(4), 787-799.

Osterlund, L. C. (2014). Wisdom in the helping relationship. Jesuit Higher Education, 3(2), 74-84.

Osterlund, L. C. (2016). Developing wisdom in counselors of the futurep. Ignatian pedagogy applied to counselor education and supervision. VISTAS Online, 1-11.

Parisi, J. M., Rebok, G. W., Carlson, M. C., Fried, L. P., Seeman, T. E., Tan, E. J., Tanner, E. K., \& Piferi, R. L. (2009). Can the wisdom of aging be activated and make a difference societally? Educational Gerontology, 35(10), pp.867879.

Phan, L. T., Rivera, E. T., Volker, M., \& Maddux, C. D. (2009). Wisdom in multicultural counselingp. In ommited ingredient. Revista Interamericana de Psicologia/Interamerican Journal of Psychology, 43(1), 154-161.

Staudinger, U. M. (1999). Older and wiser? Integrating results on the relationship between age and wisdom-related performance. International Journal of Behavioral Development, 23, 641-664.

Staudinger, U. M., Dorner, J., \& Mickler, C. (2005). Wisdom and personality. In R.J. Sternberg \& J. Jordan (Eds.). A Handbook of wisdomp. Psychological perspectives (pp. 191-219). Cambridgep. Cambridge University Press.

Staudinger, U. M. \& Gluck, J. (2011). Psychological wisdom researchp. commonalities and differences in a growing field. Annual Review Psychology, 62(1), 215-241.

Staudinger, U. M., Maciel, A. G., Smith, J., \& Baltes, P. B. (1998). What predicts 
wisdom-related performance? A first look at personality, intelligence, and facilitative experiential contexts. European Journal of Personality, 12, 1-17.

Sternberg, R. J. (1986). Intelligence, wisdom, and creativityp. Three is better than one. Educational Psychologist, 21(3), 175-190.

Sternberg, R. J. (1998). A balance theory of wisdom. Review of General Psychology, 2(1), 347-365.

Sternberg, R. J. (2001). Why schools should teach for wisdomp. the balance theory of wisdom in educational settings. Educational Psychology, 36(4), 227-245.

Sternberg, R. J. (2005a). WICSp. A model of positive educational leadership comprising wisdom, intelligence, and creativity synthesized. Educational Psychology Review, 17(3), 191-262.

Sternberg, R. J. (2005b). Foolishness. In R.J. Sternberg \& J. Jordan (Eds.). A handbook of wisdomp. Psychological perspectives (pp. 331-352). Cambridgep. Cambridge University Press.

Sternberg, R. J. (2005c). Older but not wiser? The relationship between age and wisdom. Ageing International, 30(1), 5-26.

Sternberg, R. J. (2013). Reform educationp. teach wisdom and ethics. Pbi Delta Kappan, 94(7), 44-47.

Sternberg, R. J., Jarvin, L., \& Reznitskaya, A. (2008). Teaching for wisdom through bistoryp. Infusing wise thinking skills in the school curriculum. In M. Ferrari \& Potworowski, Georges. (Eds.). Teaching for wisdomp. Cross-cultural perspectives on fostering wisdom (pp. 37-57). USAp. Springer.

Takahashi, M. (2000). Toward a culturally inclusive understanding of wisdomp. Historical roots in the East and West. The International Journal of Aging and Human Development, 51(3), 217-230.

Takahashi, M., \& Overton, W. F. (2002). Wisdom p. A culturally inclusive development perspectives. International Journal of Behavior Development, 26(3), 269-277.

Takahashi, M., \& Overton, W. F. (2005). Cultural foundations of wisdomp. An integrated developmental approach. In R.J. Sternberg \& J. Jordan (Eds.). $A$ bandbook of wisdomp. Psychological perspectives (pp. 32-60). Cambridgep. Cambridge University Press.

Tukiainen, A. (2010). Philosophical counselling as a process of fostering wisdom in the form of virtues. Practical Philosophy, 10(1), 48-57.

Webster, J. D., Westerhof, G. J., \& Bohlmeijer, E. T. (2012). Wisdom and mental health across the life span. Journals of Gerontology Series Bp. Psychological Sciences and Social Sciences, 69(2), 209-218. 